\title{
The Effects of the Regulatory Ownership on Conservatism of Accounting Firms in Tehran Stock Exchange
}

\author{
Mahboubeh Fathi Rkabdary
}

Master of Accounting, Islamic Azad University of Babol

Corresponding Author E-mail: mahboobehfathi89@yahoo.com

Received: 24 October 2018, Revised: 05 December 2018, Accepted: 20 December 2018

\begin{abstract}
The purpose of this study is to investigate the effects of the regulatory ownership on conservatism of accounting firms in Tehran Stock Exchange. In doing so, data from 121 companies listed in Tehran Stock Exchange from 1385 to 1390 were used. And using a panel analysis method alongside Eviews software, research hypotheses were investigated. To measure conservatism, two models of Shiva Kumar and Basu Ball were used. The results showed that there is a negative and significant relationship between regulatory ownership, conservatism of firms accounting sector. This means that by increasing regulatory ownership, use of conservative methods in economic units will decrease.
\end{abstract}

Keywords: Accounting conservatism, Regulatory ownership, Concentration of ownership.

\section{Introduction}

For many years in the past, economists used to assume that all parties of a corporation work for a common goal. But in the past 30 years, many companies have faced a conflict of interest between groups giving rise to proposals by economists to approach such conflicts. These cases are generally entitled as representation theory in management accounting. According to definition, agency relationship is a contract under which the employer or owner appoints an agent or a representative and gives them the authority of decisionmaking on behalf of them. Mekling and Jensen (1976) stated that in agency relationship, the goal of the owner is to maximize wealth and to achieve this goal, he monitors the agent's work and evaluates their performance. Shareholder and management interest conflict is one of the important issues in recent decades that has been considered by researchers, experts and investors. To resolve this conflict, several solutions have been proposed, among which, conservative accounting practices and on time loss identification can be noted.

\section{Definitions of Conservatism}

The concept of conservatism in accounting has a long history. According to Basu (1997), the influence of conservatism in accounting dates back at least to 500 years. Accountants have traditionally defined the concept of conservatism as law 
of overtake of losses and lack of profit overtake. In our country the Technical Committee on Corporate Audit ((theoretical concepts of financial reporting)) knows conservatism as caution, and recognizes it as one of the components of qualitative character ((being reliable)). Financial Accounting Standards Board (FASB) in its Concept Statement No. 2 has defined conservatism as a precautionary response that occurs due to uncertainty and is trying to create this reasonable assurance that uncertainty and inherent risk in the company's status have sufficiently been raised. American Institute of Certified Public Accountants (AICPA) has defined conservatism as the ways of recognizing gains and losses. This means that losses are recognized at the occurring moment and not at the time of realization, and profits are not recognized as long as they are realized. In other words, at time of uncertainty assets are valued less than liabilities.

\section{Literature}

In a study called " Institutional ownership and conservatism" with 16911 firms from 1995 to 2006, (Ramalingegowda and $\mathrm{Yu}, 2012$ ) concluded that regulatory agencies of probable conservatism are in financial reports of investment companies and this demand is higher when monitoring is direct, and when government benefits more from conservatism, they are also evident.

In a study called "the relationship between corporate governance and conservatism", Chi., et al. (2009) used Khan and Watts's (2007) model to measure accounting conservatism. They studied some of the Taiwan Stock Exchange firms from 1996 to 2004 and concluded that the companies whose most stocks are in possession of institutional shareholders require less conservative accounting.

Setayesh and Jamalianpour (2011) addressed "conservatism in financial reporting of listed companies in Tehran Stock Exchange". The results showed that in most cases there was not an asymmetric response between accounting earnings and stock returns.

Mehrani et al. (2011) studied "the relationship between institutional ownership and conservative accounting" and found that there was a positive relationship between institutional ownership and conservative accounting, suggesting that by increasing levels of institutional ownership, firms tend to be more conservative. As a result, it could be argued that the shareholders are active monitors of managers and encourage them to report earnings of higher quality through the use of more conservative accounting practices.

\section{- Iranian Accounting Standards and Conservatism}

In Iranian accounting standards, application of conservatism is fully evident. It is to such a degree that the main requirement for revenue recognition is the probable future economic benefits associated with the transaction flow within the business unit. So as long as income approach to cash flows has not been assured, it should not be identified. And if business has incurred expenses in connection with future economic benefits which are doubtful, then the fee must be paid at the happening time. In other words, standard has established more stringent criteria for revenue and assets recognition than for debt and expenditure.

Examples of the application of the conservatism of the standard are: Section 24 Accounting Standard 9 (Accounting Convention on Long-Term), Section 40 
Accounting Standard 11 (Fixed Tangible Assets), paragraph 4 of Accounting Standard 8 (Accounting Inventory Materials and products), Sections 29 and 31 and 34 accounting Standard 15 (accounting for investments), paragraphs 33.40 and 44 accounting Standard 17 (intangible Assets). Therefore, based on existing standards, we expect that items of financial statements of companies are conservatively identified and reported as well.

\section{Regulatory Ownership}

Among the corporate governance mechanisms, one of the mechanisms that are increasingly important is the rise of institutional investors. Due to owning a significant proportion of shares of the companies, institutional investors have considerable influence on the investee companies, and have the potential to influence the actions and policies adopted by the directors and can monitor managers. So, the ownership entity is also called the regulatory ownership. In this research, institutional shareholders are defined according to the Securities and Exchange Board's Act dating to $1386 / 06 / 28$ regarding the definition of institutional shareholders, which is defined as follows:

Institutional Investors, subject of paragraph of Article 27 of the Securities Market Law of the Islamic Republic of Iran include:

1- Banks and insurance;

2- Holdings, investment companies, pension funds, financing companies and investment funds registered with the Securities and Exchange

3- Every natural or legal person who buys more than $5 \%$ or buys more than 5 billion Rial of the nominal value of securities in publishes of the publisher;

4- Government and public organizations;
5- State companies;

6- Board members and administrators, publishers or persons who have the same power Exchange Information Company (2005).

In general, such firms are defined as regulatory ownership that has three characteristics of long-term investment horizon, concentrated stock management and independence from management (with no representative on the Board of Directors). Thus, supervisory owners are the same as institutional owners except for not having a representative in Board of Directors.

\section{Materials and Methods}

In terms of classification of research, based on objective, this study can be considered as a form of applied research. In terms of data collection, this study is considered to be quasi-experimental and the methodology is casual using past data.

\section{- Research Hypothesis}

Regulatory ownership has some impacts on accounting conservatism of listed companies in Tehran stock exchange.

In this study, we used two models:

- Basu Model: According to Basu (1997) conservatism causes less sustainable profits during periods of bad news than periods of good news.

Using the following model, Basu understood that asymmetry in the interest in reflecting good and bad news results in varying degrees of stability.

$$
N_{i t}=\beta_{0}+\beta_{1} D R_{i t}+\beta_{2} R E T_{i t}+\beta_{3}\left(R E T_{i t} \times D R_{i t}\right)+\varepsilon_{i t}
$$

In which:

NIit is net profit of firm $i$ in year $t$ divided by the market value of equity of firm $i$ in year $t-1$. 
RETit - annual stock return of firm $i$ in year $t$

DRit is a virtual variable, if stock returns is negative $($ RET $<0)$ it equals to one and zero otherwise.

$\beta_{2}$ - Reaction of benefit to good news is positive return.

$\beta_{2}+\beta_{3}$-Reaction of benefit to bad news is negative return.

Conservatism of accounting suggests $\beta_{2}+\beta_{3}>\beta_{2}$ which means $\beta_{3}>0$

\section{Basu Model - Regulatory Ownership}

$N I_{i t}=\beta_{0}+\beta_{1} D R_{i t}+\beta_{2} R E T_{i t}+\beta_{3}\left(R E T_{i t} \times D R_{i t}\right)+\beta_{4} M O N I T O R_{t h}$

$+\beta_{5}\left(D R_{i t} \times M O N I T O R_{i t}\right)+\beta_{6}\left(R_{E T T_{i t}} \times\right.$ MONITOR $)$

$+\beta_{l}\left(R_{T} T_{i t} \times D R_{i t} \times M O N I T O R_{i t}\right)+\varepsilon_{i t}$

Ball and Shiva Kumar Model: According to Ball and Shiva Kumar (2005), economic losses are identified faster than gains. Losses are identified accrual even before being realized. But the benefits are recognized when realized. Ball and Shiva Kumar's model meets the role of accruals items- reduction in impairment of cash flow and asymmetric recognition.

$$
A C C_{i f}=\beta_{0}+\beta_{1} D C F O_{i f}+\beta_{2} C F O_{i f}+\beta_{3}\left(C F O_{i f} \times D C F O_{i t}\right)+\varepsilon_{i f}
$$

In which:

ACCit = difference between operating profit and operating cash flow of firm $i$ in year $t$, which is homogenized based on the total value of assets in the first period of firm $i$.

CFOit $=$ operating cash flow of firm $i$ in year $t$, which is homogenized based on the total value of assets of the first year of the firm.
DCFOit $=$ is the virtual variable, if operating cash flow is negative (DCFO <0) it equals one and zero otherwise.

$\beta_{2}$ - Reaction of benefit to good news is positive return.

$\beta_{2}+\beta_{3}$-Reaction of benefit to bad news is negative return.

Conservatism of accounting suggests $\beta_{2}+\beta_{3}>\beta_{2}$ which means $\beta_{3}>0$

\section{Ball and Shiva Kumar Model - Regulatory Ownership}

$A C C_{i t}=\beta_{0}+\beta_{1} D C F O_{i t}+\beta_{2} C F O_{i t}+\beta_{3}\left(C F O_{i t} \times D C F O_{i t}\right)+\beta_{4} M O N T O R_{i}$

$+\beta_{5}\left(D C F O_{i i} \times M O N T O R_{i j}\right)+\beta_{6}\left(C F O_{i 1} \times M O N T O R_{i j}\right)$

$+\beta_{\}}\left(\mathrm{CHO}_{\mathrm{it}} \times D C F \mathrm{O}_{\mathrm{i}} \times \mathrm{MONTOR}\right)+\varepsilon_{i \mathrm{i}}$

And in these models:

MONITORit $=$ Regulatory ownership of firm $i$ in year $t$

$\varepsilon i t=$ the error for firm $i$ in year $t$

To test the main hypothesis of the study, the only independent variable of the study (regulatory ownership) is included in the model.

\section{The Population and Sampling Factor Analysis}

In the present study, for the sample to be a proper representative of the population, at first screening method Factor analysis has been used.

For this purpose, the following criteria have been considered. If a firm has all the criteria, it has been selected as one of the firms of population. The criteria are as follows:

1- They should be listed in stock before 1385 and be active until the end of 1390 .

2- For the information to be comparable firms should not have financial change 
during the study and the end of their financial year is 29th of Esfand.

3- To the homogeneity of information, they should not be among investment firms or financial intermediation including banks or insurance companies.

Thus, from among the firms included in 121 companies listed in Tehran Stock Exchange from 1385 to 1390 were selected randomly.

\section{Results}

The Findings of Testing the Main Hypothesis Based on Basu Model (1997)

Positiveness (negativeness) and significance of coefficient of $\left.\beta_{\text {( }} R E T \times D R \times M O N T O R\right)$ indicates that by increasing regulatory ownership, the level of corporate accounting conservatism (decreases) increases. So according to the amount and significance level of the coefficient of $\beta_{7}$ based on Basu (1997) model it is decided to accept or reject the main hypothesis of the research.

As is seen from the result obtained in Table 1, coefficient of variable $\left(\beta_{7}\right) R E T \times D R \times M O N T O R$ equals $0 / 3810$ and its significance level equals to 0.0359 . Thus, it can be stated that there is a negative and significant relationship between the regulatory ownership and accounting conservatism of listed firms in Tehran Stock Exchange with less than 5\% error level. As a result, the main hypothesis of the research based on Basu's (1997) model is confirmed.

Table 1. Results of the first regression model

\begin{tabular}{cccc}
\hline Variables & Coefficient & Student's t-test & $\begin{array}{c}\text { Significance } \\
\text { level }\end{array}$ \\
\hline Constant & 0.2280 & 3.5847 & 0.0004 \\
$D R\left(\beta_{1}\right)$ & 0.0442 & 1.0881 & 0.2770 \\
$R E T\left(\beta_{2}\right)$ & 0.1464 & 3.9818 & 0.0001 \\
$R E T \times D R\left(\beta_{3}\right)$ & 0.3050 & 2.1296 & 0.0336 \\
$M M N T O R\left(\beta_{4}\right)$ & -0.0396 & -0.4637 & 0.6430 \\
$D R \times M O N T O R\left(\beta_{5}\right)$ & -0.1100 & -2.1078 & 0.0355 \\
$R E T \times M O N T O R\left(\beta_{6}\right)$ & -0.0662 & -1.3914 & 0.1646 \\
$R E T \times D R \times M O N T O R\left(\boldsymbol{\beta}_{7}\right)$ & -0.3810 & -2.1031 & 0.0359 \\
Adjusted ${ }^{2}$ & & 0.5626 & \\
F-statistic & & 8.3447 & \\
Prob(F-statistic & & 0.0000 & \\
Durbin-Watson & & 1.9582 & \\
\hline
\end{tabular}

The research findings of main hypothesis of the research was based on Shiva Kumar and Ball model (2005).

Positiveness (negativeness) and significance of coefficient of
$\beta_{7}(C F O \times D C F O \times M O N T O R)$ indicates that by increasing regulatory ownership of firms, the level of corporate accounting conservatism (decreases) increases. So according to the amount and significance 
level of the coefficient of $\beta_{7}$ based on Shiva Kumar and Ball's model (2005) it is decided to accept or reject the main hypothesis of the research. As is seen from the result obtained in Table 2, coefficient of variable

$\left(\beta_{7}\right) C F O \times D C F O \times M O N I O R$ equals $3 / 3327$, and its significance level equals to

Table 2. Results of the second regression model

\begin{tabular}{cccc}
\hline Variables & Coefficient & Student's t-test & $\begin{array}{c}\text { Significance } \\
\text { level }\end{array}$ \\
\hline Constant & 0.5527 & 5.7461 & 0.0000 \\
$D C F O\left(\beta_{1}\right)$ & -0.1377 & -1.0532 & 0.2927 \\
$C F O\left(\beta_{2}\right)$ & -2.3387 & -8.37361 & 0.0000 \\
$C F O \times D C F O\left(\beta_{5}\right)$ & 1.8458 & 1.7735 & 0.0766 \\
MONTOR $\left(\beta_{4}\right)$ & -0.6569 & -5.2372 & 0.0000 \\
$D C F O \times M O N T O R\left(\beta_{5}\right)$ & 0.2464 & 1.4748 & 0.1408 \\
$C F O \times M O N I T O R\left(\beta_{6}\right)$ & 2.5867 & 8.6879 & 0.0000 \\
$C F O \times D C F O \times M O N T O R\left(\boldsymbol{\beta}_{7}\right)$ & -3.3327 & -2.5555 & 0.0108 \\
Adjusted R & & 0.2630 & \\
F-statistic & & 3.0373 & \\
Prob(F-statistic & & 0.0000 & \\
Durbin-Watson & & 1.7127 & \\
\hline
\end{tabular}

The results obtained are compatible with the results of research by Qi et al., (2009), but the not compatible with the results of research by Ramalingegowda and $Y u$ (2012) and Mehrani et al., (2011).

\section{Conclusions}

Surge of recent financial scandals in the world has led the fingers to be pointed at financial reporting. Regulatory investors have some incentives for managers' monitoring and financial reporting. Financial Statements comprise the core of financial reporting process. Among financial statements, profit and loss are an important source of information about the firm. Earnings quality has various aspects
0.0108 and this is less than $5 \%$ error level. Thus, it can be stated that there is a negative and significant relationship between the regulatory ownership and accounting conservatism of firms. Therefore, the main hypothesis of the research based on Shiva Kumar and Ball's model (2005) is confirmed. and in this research we discussed the conservatism aspect. For measuring conservatism two models of Basu and Ball and Shiva Kumar are used. In this study, we examined the relationship between conservatism and regulatory ownership, and concluded that there is a significant negative relationship between these two cases, which means any increase in the regulatory ownership reduces the use of conservatism in financial unit.

\section{Suggestions for Further Research}

Identifying variables influencing accounting conservatism and its various aspects has always been the subject of much research in different countries, and 
have been one of the basic needs of investors, creditors and analysts. Considering the limitations and also the findings of this study, the researcher's suggestions for further research are:

1- In this study the only variable considered was regulatory ownership so the effects of other probable variables that are in a shared border with this variable can be analyzed, variables such as: State ownership, managerial ownership, individual ownership, board independence, and so on.

2- Studying the effects of regulatory ownership on conditional and unconditional conservatism.

3- The relationship between the quality of corporate governance and accounting conservatism.

4- The effect of accounting conservatism on managers' bonuses.

\section{References}

Ball, R, Shivakumar, L, (2005). Earnings quality in UK private firms: comparative loss recognition timeliness. Journal of Accounting and Economics, 39: 83-128.

Basu, S. (1997). The Conservatism Principle and the Asymmetric Timeliness of Earnings. Journal of Accounting and Economics, 24(1): 3-37.
Chi, W, liu, CH , Wang, T. (2009). What affects accounting conservatism: A corporate governance perspective. Journal of Contemporary Accounting \& Economics, 5(1):47-59.

Jensen, M.C, Meckling, W.H. (1976). Theory of the firm: managerial behavior, agency costs and ownership structure. Managerial and decision economics, 25: 537 -547.

Mehrani, S, Moradi, M, Eskandar, H. (2011). The relationship between institutional ownership and conservative accounting, Financial Accounting Research, 2(1): 47-62.

Ramalingegowda, S, Yu, Y. (2012). Institutional ownership and conservatism. Journal of accounting and economics, 53(1):98-114.

Securities Market Law of the Islamic Republic of Iran, (2005), Tehran: Stock Exchange Publications.

Setayesh, M.R, Jamalianpoor, M. (2011). Checking conservatism in financial reporting of listed firms in Tehran Stock Exchange. Journal of Advances in Accounting, University of Shiraz, 2(1): 85119.

How to cite this article: Mahboubeh Fathi Rkabdary, The Effects of the Regulatory Ownership on Conservatism of Accounting Firms in Tehran Stock Exchange. International Journal of Advanced Studies in Humanities and Social Science, 2019, 8(4), 362-368. http://www.ijashss.com/article 84384.html 